Original Paper

\title{
Pelatihan Pembuatan Preparat Kromosom Dan Peyusunan Karyotipe di Fakultas Mipa Program Studi Biologi Universitas Islam Al-Azhar Mataram
}

\author{
I Gde Mertha ${ }^{1 *}$, Syamsul Bahri ${ }^{1}$, L. Zulkifli ${ }^{1}$, Agus Ramdani ${ }^{1}$, Nur Lestari ${ }^{1}$ \\ ${ }^{1}$ Program Studi Pendidikan Biologi, Fakultas Keguruan dan Ilmu Pendidikan, Universitas Mataram, Indonesia
}

DOI: $10.29303 /$ jpmpi.v2i1.358

Sitasi: Merta, I. G., Bahri, S., Zulkifli, L., Ramdani, A., Lestari, N. (2019). Pelatihan Pembuatan Preparat Kromosom Dan Peyusunan Karyotipe di Fakultas Mipa Program Studi Biologi Universitas Islam Al-Azhar Mataram. Jurnal Pengabdian Magister Pendidikan IPA (JPMPI). (2) 1. pp. 75-78

*Corresponding Author: I Gde Mertha, Program Studi Pendidikan Biologi, Fakultas Keguruan dan Ilmu Pendidikan, Universitas Mataram, Indonesia;

Email: igdemertha@yahoo.co.id

\begin{abstract}
Dalam upaya meningkatkan mutu penelitian dan pembelajaran genetika dan sitotaksonomi di perguruan tinggi diperlukan keterampilan teknik pembuatan sediaan kromosom. Sediaan kromososm tahap metafase yang menunjukkan bentuk morfologi yang jelas dan tersebar dengan baik (tidak tumpang tindih) sangat diperlukan dalam pembuatan karyotipe. Untuk mendapatkan gambaran kromosom tersebut diperlukan latihan yang intensif dalam preparasinya. Pengabdian ini bertujuan untuk memberikan pelatihan teknik pembuatan preparat untuk pengamatan bentuk morfologi kromosom yang tersebar dengan baik dan teknik penyusunan karyotipe dalam bentuk karyogram dan idiogram di Program Studi Biologi, Fakultas MIPA, Universitas Islam Al-Azhar Mataram. Penyampaian materi pelatihan dilakukan dengan menggunakan beberapa metode, yaitu ceramah, tanya jawab, diskusi, dan unjuk kerja berupa kegiatan praktek pembuatan preparat kromosom tahap metafase dengan perlakuan kolkisin, serta penyusunan karyotipe yang disajikan dalam bentuk karyogram dan idiogram. Berdasarkan hasil pengamatan selama pelatihan berlangsung dapat disimpulkan hasil yang dicapai dalam kegiatan pengabdian ini, yaitu: (1) Kegiatan pelatihan pembuatan preparat untuk pengamatan morfologi bentuk kromosom dan penyusunan karyotipe direspon positif oleh peseta pelatihan sebagai keterampilan yang sangat bermanfaat untuk menunjang kualitas pengajaran dan penelitian, (2) Minat yang tinggi peserta pelatihan dalam mengikuti praktikum meningkatkan kemampuan mikroteknik preparasi kromosom yang sangat berharga bagi pengembangan ilmu yang didalami dan penelitiannya, (3) Penuntun praktikum mikroteknik pembuatan sediaan untuk pengamatan morfologi bentuk kromosom yang telah disusun tim pengabdian dapat menjadi acuan ilmiah peserta pelatihan dalam praktikum dan penelitian.
\end{abstract}

Kata Kunci: Kromosom; Preparat Squash; Karyotype; Idiogram

\section{Pendahuluan}

Beban kewajiban dosen sebagai penggerak pendidikan di perguruan tinggi cukup berat. Seorang dosen tidak saja bertugas dalam mengajar tetapi juga kewajiban lain seperti kemampuan membimbing dan meneliti dan pengabdian bidang ilmunya terhadap masyarakat. Perkembangan ilmu dan teknologi yang sangat pesat, menuntut dosen bersifat aktif sehingga dapat mengimbangi perubahan dan perkembangan yang terjadi. Dengan demikian dosen harus selalu berusaha melakukan inovasi ilmunya melalui berbagai cara seperti kegiatan penelitian.

Kegiatan penelitian yang dilaksanakan dosen di perguruan tinggi dalam upaya memecahkan masalah dan menemukan hal-hal baru bidang sains yang inovatif bagi masyarakat tidaklah gampang jika keterampilan laboratorium tidak dikuasai dengan baik. Diperlukan kemampuan dasar, pengalaman, dan keterampilan yang memadai dalam metode dan teknik-teknik penelitian yang 
terus berkembang (Setiadi, 2000). Seorang dosen wajib mengikuti perkembangan teknik-teknik penelitian terbaru di laboratorium jika ingin mendapat hasil yang lebih baik. Untuk itu, kegiatan penelitian dosen harus ditunjang pula oleh kemampuan teknisi laboratorium yang memadai dibidangnya.

Sediaan kromosom merupakan salah satu preparat yang sangat penting dalam praktikum dan pengajaran genetika dan sitotaksonomi. Gambaran kromososm yang diperoleh dosen selama ini banyak diperoleh dari gambar-gambar skematis atau foto yang terdapat pada buku-buku teks dan literatur terkait. Jarang dilakukan pengamatan kromosom di laboratorium, karena pembuatan preparat ini membutuhkan keterampilan khusus. Sangat sedikit informasi yang diperoleh jika pengamatan kromosom hanya didasarkan pada gambar-gambar yang terdapat pada buku tersebut. Untuk dapat menelaah kromosom secara detail, maka pengamatan mikroskopis penting dilakukan.

Gambar bentuk-bentuk kromosom yang telah didokumentasikan dibawah mikroskop akan bisa digunakan sebagai data dalam analisis genetik apabila telah disusun menjadi karyotipe. Menurut Levitsky (dalam Rieger et al., 1991), karyotipe merupakan komplemen kromosom dari suatu individu, biasanya didasarkan atas morfologi kromosom pada metafase dari mitosis. Suryo (1996) mendefinisikan karyotipe sebagai gambar susunan kromosom dari sel somatik suatu individu menurut standar berdasarkan panjang, jumlah serta bentuk kromosom. Studi karyotipe terutama ditekankan pada aspek-aspek morfologi kromosom, seperti ukuran dan bentuk kromosom dari komplemen yang sama bersama-sama dengan jumlah kromosom (Sivarajan, 1984 dalam Mertha, 2001). Kromosom-kromosom biasanya disusun berderet mulai dari ukuran terpanjang sampai yang terpendek sebagai suatu karyogram dan jika disajikan dalam bentuk diagram disebut idiogram (Radford et al., 1974; Singh, 1993) sehingga akan memudahkan analisis.

Hambatan utama yang dialami dosen ketika akan merencanakan penelitian dan membimbing praktikum genetika pada materi kromosom karena mereka banyak belum mengenal teknik yang benar dalam pembuatan preparat untuk pengamatan kromosom dibawah mikroskop dan penyusunan karyotipe dalam bentuk karyogram dan idiogram. Dalam upaya meningkatkan mutu penelitian dan pembelajaran genetika (sitogenetika) serta sitotaksonomi di perguruan tinggi diperlukan keterampilan teknik pembuatan sediaan kromosom dan penyusunan karyogram. Oleh karena itu dengan kegiatan pengabdian ini dosen diharapkan dapat mengembangkan keahliannya dan dapat meningkatkan kualitas penelitian dan pengajaran. Dengan demikian akan mendukung peningkatan prestasi mahasiswa secara keseluruhan.

Kegiatan ini bertujuan untuk memberikan pelatihan tentang teknik pembuatan preparat untuk pengamatan bentuk morfologi kromosom yang tersebar dengan baik dan teknik penyusunan karyotipe yang disajikan dalam bentuk karyogram dan idiogram di Program Studi Biologi, Fakultas MIPA, Universitas Islam Al-Azhar Mataram. Pada kegiatan ini peserta dilatih membuat sendiri preparat kromosom metafase, pengamatan mikroskopis, dan teknik penyusunan kromosom dalam karyogram dan idiogram.

Manfaat yang diharapkan dari kegiatan pelatihan ini, yaitu: (1) menambah wawasan dosen tentang mikroteknik pembuatan preparat kromosom dan penyusunan karyotipenya, (2) keterampilan membuat preparat kromosom akan meningkatkan kemampuan dosen dalam penelitian dan bimbingan praktikum mahasiswa dalam bidang genetika khususnya sitogenetika dan bidang sitotaksonomi yang banyak mengkaji kromosom.

Pemecahan masalah berkaitan dengan mikroteknik pembuatan preparat kromosom tahap metafase dengan metode squash untuk penyusunan karyotipe dalam bentuk karyogram dan idiogram di Program Studi Biologi, Universitas Islam Al-Azhar dilakukan dengan langkah-langkah sebagai berikut: (1) Tahap persiapan, dilakukan penyiapan alat dan bahan yang akan digunakan pada saat pelatihan. Kegiatan persiapan ini meliputi: (a) Penyiapan kemikalia untuk pembuatan fiksatif dan pewarna kromosom. Pewarna kromosom yang digunakan adalah carbolic fuchsin. Staining ini akan berfungsi dengan baik apabila telah diperam selama 1 bulan sebelum digunakan, (b) Pembuatan atau penyusunan materi untuk presentasi, (c) Penanaman bawang bawang bombay (Allium cepa) pada media air dalam gelas aqua dan penyemaian biji kemuning jepang (Murraya exotica) pada media tissue basah, kedua langkah ini bertujuan untuk menumbuhkan akar sebagai sumber jaringan meristematik. Kegiatan ini berlangsung selama 4-7 hari, (d) Koordinasi tim mengenai rencana kegiatan pengabdian, dan (e) Pertemuan anggota pengabdian untuk membahas materi dan teknis kegiatan 
pelaksanaan pengabdian. Segala informasi yang berkaitan dengan kondisi lapangan tempat pelatihan dikumpulkan, demikian pula literatur yang relevan yang akan menunjang kegiatan pelatihan; (2) Tahap observasi, dilakukan peninjauan langsung terhadap kondisi lapangan tempat pelatihan. Tim pengabdian berkoordinasi dengan pihak Universitas Islam AlAzhar Program Studi Biologi berkaitan dengan jadual pelaksanaan kegiatan pengabdian. Pada lokasi ini tim melakukan observasi, menganalisis situasi dan kondisi dosen serta tenaga teknisi di laboratorium. Pada kegiatan turun lapangan ini, tim juga mempelajari situasi yang akan mendukung dan menghambat kegiatan agar dapat ditentukan alternatif pemecahannya. Diskusi dengan calon peserta pelatihan dilakukan untuk mendapat gambaran tentang situasi yang akan menunjang dan menghambat kegiatan, agar sejak awal dapat dicarikan solusi untuk mengatasinya. Pada tahap ini disepakati jadual kegiatan pelatihan; (3) Tahap pelaksanaan, disampaikan materi pengabdian mikroteknik pembuatan preparat kromosom, teknik penysunan karyotipe dalam bentuk karyogram dan idiogram, serta bimbingan pengamatan kromosom dibawah mikroskop; (4) Tahap penyusunan laporan dan publikasi, semua data yang diperoleh mulai dari penyampaian materi, kegiatan keterampilan praktek pembuatan preparat dan tanggapan peserta serta hasil diskusi selama kegiatan pengabdian berlangsung di laboratorium dihimpun dan dilakukan analisis sebagai bahan dalam penyusunan laporan dan publikasi hasil pengabdian.

\section{Metode Pelaksanaan}

Penyampaian materi pelatihan dilakukan dengan menggunakan beberapa metode, yaitu ceramah, tanya jawab, diskusi, dan unjuk kerja berupa kegiatan praktek pembuatan preparat kromosom tahap metafase dengan perlakuan kolkisin, teknik dokumentasi, serta penyusunan karyotipe dalam bentuk karyogram dan idiogram.

Untuk meyakinkan bahwa praktek pembuatan preparat morfologi kromosom dan karyogram telah dilaksanakan dengan benar maka dilakukan refleksi dalam upaya pembinaan. Pada kegiatan ini dilakukan diskusi untuk membahas kesulitan-kesulitan yang dihadapi selama praktek mikroteknik pembuatan preparat kromosom dan penyusunan komplemen kromosom dalam karyogram dan ideogram.

\section{Hasil dan Pembahasan}

Setelah dilakukan pelatihan pembuatan sediaan atau preparat untuk pengamatan bentuk morfologi kromosom dengan metode squash, para peserta menjadi sangat antusias. Hal ini tampak ketika dilakukan praktikum, mereka secara perorangan sangat serius membuat preparat. Dengan tekun mereka mengamati preparat kromosom yang telah dibuat dibawah mikroskop. Demikian pula pada pada saat penyusunan karyogram dan idiogram, tugas tersebut dilakukan dengan penuh tanggung jawab. Jika mengalami kesulitan mereka banyak bertanya.

Kegiatan praktikum pembuatan preparat untuk pengamatan morfologi kromosom menambah wawasan pengetahuan dan keterampilan yang sangat penting bagi dosen dan teknisi laboratorium dalam mengemban tugas mereka dalam membimbing praktikum mahasiswa dan melakukan kegiatan penelitian. Dengan melakukan kegiatan pembuatan preparat kromosom yang mencakup pengambilan cuplikan ujung akar, pre-treatment dengan kolkisin, fiksasi, hidrolisis, staining, dan squashing, para peserta pelatihan mendapat pengalaman baru mikroteknik untuk visualisasi materi genetik yang mengalami kondensasi membentuk kromosom. Hasil pengamatan menunjukkan bahwa hampir semua peserta dapat mempraktekkan semua langkah pembuatan preparat kromosom tersebut dengan baik dan benar sehingga kromosom tersebar (tidak atau sedikit tumpang tindih). Demkian juga letak sentromer teridentifikasi dengan baik sehingga memudahkan penentuan bentuk kromosom. Beberapa kesulitan yang dihadapi para peserta pada enam langkah proses pembuatan preparat diatas umumnya terjadi pada kegiatan pre-treatment, hidrolisis dan squashing. Beberapa preparat hasil kerja peserta menunjukkan kromosom yang menggumpal satu sama lain pada saat diamati dibawah mikroskop. Hal ini kemungkinan disebabkan waktu pretreatment yang kurang tepat dan squashing yang belum merata atau tekanan kurang kuat. Melalui latihan berulang-ulang dengan perbaikan pada kedua langkah tersebut, kendala itu dapat diatasi. Kendala lain yang ditemukan adalah warna kromosom yang terpulas sangat pucat. Masalah ini dapat diatasi dengan perlakuan hidrolisis yang tidak terlalu lama atau tidak terlalu cepat. Hal ini sesuai dengan pernyataan Jones dan Rickards (1991) 
bahwa waktu yang ideal untuk hidrolisis adalah 10 menit.

Antusias dosen dan teknisi dalam menyusun karyotipe dalam bentuk karyogram dan idiogram direspon positif oleh peserta pelatihan. Penyusunan karyogram dan idiogram pada pelatihan ini mengikuti petunjuk Mertha (2001). Para peserta pelatihan mengamati preparat dibawah mikroskop. Kromosom tahap metafase yang menunjukan penyebaran secara baik dipotret pada perbesaran 1000x. Karyogram dan idiogram dibuat dari gambar kromosom hasil pemotretan. Foto kromosom digunting sesuai bentuknya. Kromosom yang telah digunting diberi nomor secara acak dan selanjutnya dipasangkan sesuai homolognya dan disusun berjejer dari pasangan ukuran terbesar sampai pasangan ukuran terkecil. Rata-rata panjang lengan pasangan homolog kromosom absolut dari lima sel somatik dijadikan dasar dalam penyusunan idiogram. Semua peserta pelatihan telah menyelesaikan penyusunan karyotipe ini dengan teliti dan penuh kesabaran. Karyogram yang disusun menggunakan kromosom berukuran besar pada bawang bombay (Allium cepa) lebih mudah diselesaikan dibandingkan dengan kromosom berukuran kecil pada kemuning jepang (Murraya exotica). Pada kromosom yang berukuran kecil, untuk memperjelas bentuk kromosom dilakukan penjiplakan kromosom menggunakan plastik transparan. Kromosom yang telah digambar pada plastik tersebut digunting, dan selanjutnya digunakan dalam penyusunan karyogram. Semua kegiatan tersebut telah sukses dikerjakan peserta pelatihan dengan hasil baik.

Berdasarkan hasil kerja praktek yang telah dilakukan dosen dan teknisi laboratorium diatas, maka kegiatan pengabdian ini telah mencapai sasaran sesuai target dalam tujuan kegiatan. Hal ini terbukti bahwa dosen dan teknisi sangat tekun dan sukses membuat preparat untuk pengamatan bentuk morfologi kromosom, pengamatan preparat hasil pelatihan dibawah mikroskop, dan penyusunan karyotipe dalam bentuk karyogram dan idiogram dengan baik dan benar.

\section{Kesimpulan}

Berdasarkan hasil pengamatan selama kegiatan pelatihan dan evaluasi secara menyeluruh, dapat disimpulkan: (1) Kegiatan pelatihan pembuatan preparat untuk pengamatan morfologi bentuk kromosom dan penyusunan karyotipe direspon positif oleh peseta pelatihan sebagai keterampilan yang sangat bermanfaat untuk menunjang kualitas pengajaran dan penelitian, (2) Minat yang tinggi peserta pelatihan dalam mengikuti praktikum meningkatkan kemampuan mikroteknik preparasi kromosom yang sangat berharga bagi pengembangan ilmu yang didalami dan penelitiannya, (3) Penuntun praktikum mikroteknik pembuatan sediaan untuk pengamatan morfologi bentuk kromosom yang telah disusun tim pengabdian dapat menjadi acuan ilmiah peserta pelatihan dalam praktikum dan penelitian.

\section{Saran}

Dalam upaya lebih meningkatkan profesionalisme dosen dan teknisi perlu dilakukan pengabdian masyarakat yang lebih mendalam pada tingkal laku kromosom saat meiosis.

\section{Daftar Pustaka}

Jones, R.N. dan C.K. Rickards. 1991. Practical Genetics. John Wiley \& Sons, New York.

Mertha, I.G. 2001. Karyotipe Murraya exotica L. dan Murraya paniculata (L.) Jack. di Jawa Sebagai Bukti Taksonomi. Tesis S-2 Program Pasca Sarjana, Univerrsitas Gadjah Mada, Yogyakarta.

Radford, A.E., W.C. Dickison, J.R. Massey, dan C.R. Bell. 1974. Vascular Plant Systematics. Harper \& Row Publishers, New York.

Rieger, R., A. Michaelis, dan M.M. Green. 1991. Glossary of Genetics - Clasical and Molecular. $5^{\text {th }}$ ed. Springer-verlag, Berlin Heiddelberg.

Setiadi, D. Teknik-Teknik Pengujian Efek Produk Alam Terhadap Fertilitas Hewan. Laporan Kegiatan Tidak Bergelar. Program Studi Pendidikan Biologi, Universitas Mataram.

Singh, R.J. 1993. Plant Cytogenetic. CRC Press, London.

Suryo, 1996. Genetika. Gadjah Mada University Press, Yogyakarta. 